\title{
APPLICABILITY OF THE USE OF WASTE FROM DIFFERENT BANANA CULTIVARS FOR THE CULTIVATION OF THE OYSTER MUSHROOM
}

\section{Cristiane Suely Melo de Carvalho ${ }^{1}$, Lorena Vieira Bentolila de Aguiar ${ }^{2}$, Ceci Sales-Campos ${ }^{2}$, Marli Teixeira de Almeida Minhoni $^{3}$, Meire Cristina Nogueira de Andrade ${ }^{3^{*}}$}

${ }^{1}$ Universidade Federal do Amazonas, Centro de Apoio Multidisciplinar, Manaus, AM, Brasil; ${ }^{2}$ Instituto Nacional de Pesquisas da Amazônia, Coordenação de Pesquisas em Produtos Florestais, Manaus, AM. ${ }^{3}$ Universidade Estadual Paulista, Faculdade de Ciências Agronômicas, Departamento de Produção Vegetal, Módulo de Cogumelos, Botucatu, SP, Brasil.

Submitted: February 22, 2011; Returned to authors for corrections: August 10, 2011; Approved: January 16, 2012.

\begin{abstract}
The objective of this research was to evaluate the oyster mushroom Pleurotus ostreatus- (Jacq.: Fr.) Kumm. cultivation in substrates based on different combinations of wastes (leaf, pseudo-stem and pseudo-stem + leaf) and banana cultivars - Musa spp. (Thap Maeo, Prata Anã, Pelipita and Caipira) during 49 days. Organic matter loss in the substrate by action of the fungus was also evaluated during that period. It was verified that the pseudo-stem waste provided the best averages of biological efficiency among all cultivars tested and best rates were obtained by Thap Maeo (61.5\%). The highest organic matter loss (OML) was obtained from pseudo-stem + leaf wastes (Prata Anã - 78.6\%; Thap Maeo - 67.6\%; Pelipita - 64.8\%; Caipira - 60.6\%). Therefore, the use of those wastes showed itself viable for $P$. ostreatus cultivation due to its availability and low cost, besides decreasing discards to environment.
\end{abstract}

Key words: Pleurotus ostreatus, mycelium, organic matter, biological efficiency, supplementation.

\section{INTRODUCTION}

The oyster mushroom is the third most cultivated edible mushroom in the world (24). There isn't official statistics about mushroom production in Brazil, but different Pleurotus species have been cultivated and $P$. ostreatus is the most important oyster mushroom grown in that country (30).

Fungi belonging to the Pleurotus genus, also known as white rot wood fungi, develop with efficiency in lignocellulosic wastes, such as wheat and corn straw, wastes from cotton and coconut, sugar cane bagasse, sawdust, etc. They have specific enzymes that degrade lignocelulosic compounds present in those types of raw material $(1,5)$. The waste from the banana tree is another material with high potential for utilization as substrate in edible mushroom cultivation $(4,17,29,32)$.

The banana is the third most exported fruit in Brazil (10); the Northern region the third biggest producer. The state of Amazonas is the second biggest producer in that region, followed by the state of Pará. After the production of the

\footnotetext{
*Corresponding Author. Mailing address: Universidade Estadual Paulista, Faculdade de Ciências Agronômicas, Departamento de Produção Vegetal, Módulo de Cogumelos. Rua José Barbosa de Barros, 1780, Fazenda Lageado, Caixa Postal 237, CEP 18610-307, Botucatu, SP.; E-mail: mcnandrade@hotmail.com
} 
banana bunch, which occurs only once and usually 18 months after cultivation, most of the banana tree is discarded and only $50 \mathrm{~cm}$ of the pseudo-stem is left to serve as source of nutrition to the sprouts (2).

Considering that the pseudo-stem and the adult plant reach about 1.2 to 1.8 meters high and their weight of approximately 10 to $100 \mathrm{~kg}$, a huge amount of waste is generated after harvest $(6,7)$. Both pseudo-stem and leaves of the banana tree have high content of lignolitic fibers (31), with high potential for development of edible mushrooms.

The Pleurotus spp cultivation carried out with that waste lead to satisfactory results in relation to enzyme production in substrate degradation and productivity obtained in cultivation $(17,22,29,32)$. The cultivation technology of edible mushrooms in the Amazon region is still little developed. Thus, considering that the region presents high potential to such pratice due to the great availability of timber and agricultural wastes (26), researches are necessary to spread the knowledge obtained and provide popularity to the product.

Therefore, the objective of this work was to evaluate the production of $P$. ostreatus in substrates based on wastes (leaf, pseudo-stem and pseudostem + leaf) of four banana cultivars (Thap Maeo, Prata Anã, Pelipita and Caipira), as well the organic matter loss of the substrates by the fungus action.

\section{MATERIALS AND METHODS}

The experiments were carried out at the Edible Fungus Cultivation Laboratory of the Coordination of Research in Forest Products - CPPF, Amazônia National Research Institute (INPA), Manaus, Amazonas, Brazil, in the period from February to June, 2009.

The $P$. ostreatus strain used was POS 09/100, proceeding from the Mushrooms Module of the School of Agronomic Sciences, UNESP, Botucatu, São Paulo, Brazil. According to the records of the Institute, the strain was obtained from a commercial grower from the region of Sorocaba/SP. That strain is stored (in mineral oil) at the mycology collection of the Edible Fungus Cultivation Laboratory of the CPPF/INPA.

Wastes from banana tree cultivars belonging to the Musa spp genus of cultivars Thap-Maeo, Prata-anã, Pelipita and Caipira (genomic groups $\mathrm{AAB}, \mathrm{AAB}, \mathrm{ABB}$ and $\mathrm{AAA}$, respectively) were obtained from the experimental unit of Embrapa Amazônia Ocidental, Rod. AM-10, Km 29, Manaus, Amazonas, Brazil. Pseudo-stems and leaves were collected and then processed by chopping leaves in a DPM 4, 3.300 RPM forage chopper, according to the methodology described by Sales-Campos (27). The chopped material was distributed in nets and submitted to natural drying. After that procedure, they were stored in raffia bags until the beginning of the experiments. The pseudo-stem was firstly sectioned in the middle and then exposed to environmental temperature until the reduction of water excess. The wastes were processed in the same chopper previously used and stored in nets, in order to complete the drying process, which was also naturally carried out. After, they were stored in raffia bags until the beginning of the experiments.

The experiment was totally randomized in $3 \times 4$ factorial scheme, corresponding to 3 combinations of wastes (pseudostem, leaf and pseudo-stem + leaf) and 4 banana cultivars (Thap-Maeo, Prata-anã, Pelipita and Caipira), with 6 repetitions, totalizing 72 experimental units (Table 1). The data was submitted to ANOVA variance analysis by using the SISVAR 4.2 statistic program, developed by the Department of Exact Sciences of the Federal University of Lavras, Minas Gerais, Brazil. (UFLA). Next, the averages were compared by using the Tukey test with $5 \%$ of probability.

A primary matrix of the POS $09 / 100$ strain of $P$. ostreatus was used for the production of the spawn (secondary matrix), which was inoculated in Petri dishes containing PDA (Potato Dextrose Agar) medium.

The substrate used for $P$. ostreatus growth was prepared individually, according to waste types (pseudo-stem, leaf and pseudo-stem + leaf) (Table 1). The mixture made up with $80 \%$ 
of waste and $20 \%$ of wheat bran was added with distilled water until reaching $75 \%$ of moisture. After that, the substrate was inserted into 72 PEAD bags (Polyetilene of High Density) with cotton vent in the upper lateral, in the proportion of $200 \mathrm{~g}$ for each package. The bags were hot-sealed and sterilized at $121^{\circ} \mathrm{C}$ for 60 minutes.

Table 1. Treatments utilized for production of the POS 09/100 strain of Pleurotus ostreatus in substrates based on banana waste plus $20 \%$ of wheat bran.

\begin{tabular}{cc}
\hline Waste & Banana cultivar \\
\hline Pseudo-stem & Thap-Maeo \\
Leaf & \\
Pseudo-stem + leaf $(1: 1)$ & Prata-anã \\
Pseudo-stem & \\
Leaf & \\
Pseudo-stem + leaf $(1: 1)$ & Pelipita \\
Pseudo-stem & \\
Leaf & \\
Pseudo-stem + leaf $(1: 1)$ & Caipira \\
Pseudo-stem & \\
Leaf & \\
Pseudo-stem + leaf $(1: 1)$ &
\end{tabular}

After substrate cooling, each package was weighed and cuts were made at the sides of each bag inside a laminar flow chamber. Through this hole, a sectioned round segment of the inoculum was added to each substrate. The bags were hotsealed again, identified and randomly distributed in a BOD incubation chamber (Biological Oxygen Demand) adjusted to $25^{\circ} \mathrm{C}$ and air moisture of $95 \%$, until total colonization of the substrate.

The primordia induction occurred after the complete colonization of the substrate, 20 days after the inoculation. For that, the incubation temperature was dicreased to $20^{\circ} \mathrm{C}$ and maintained during 24 hours. After that, the BOD was adjusted back to the previous temperature $\left(25^{\circ} \mathrm{C}\right)$. After the second day from thermal shock (22 days after inoculation), primordia formation occurred in some treatments and in the $4^{\text {th }}$ day after the shock, the first harvest was manually performed, before the sporulation stage, by withdrawing the whole branch. Next, the stem was cleaned to avoid harvest wastes. Then, productivity was expressed by means of biological efficiency (BE), which represents conversion percentage of the substrate into fungic biomass (mushrooms), established by the formula:

$$
\mathrm{BE}(\%)=\frac{\text { total fresh mass of mushrooms }(\mathrm{g})}{\text { inicial dry mass of substrate }(\mathrm{g})} \times 100
$$

The organic matter loss (OML) was also evaluated, which represents the decomposition of the substrate by the fungus, determined by the formula:

$$
\operatorname{OML}(\%)=\frac{\text { inicial substrate dry mass }(\mathrm{g})-\text { residual }(\mathrm{g})}{\text { inicial substrate dry mass }(\mathrm{g})} \times 100
$$

The $\mathrm{C}: \mathrm{N}$ ratio (carbon/nitrogen) determination was carried out according to Lanarv's (14) method. Samples of the initial substrate were analyzed at the Fertilizers and Correctives Laboratory of the FCA/UNESP, Botucatu-SP.

The data of the experiments were submitted to ANOVA variance analysis, by using the SISVAR 4.2 statistical software, developed by the Department of Exact Sciences of the Federal University of Lavras, Minas Gerais (UFLA). Averages were compared by the Tukey's test with 5\% of probability. 


\section{RESULTS AND DISCUSSION}

The cultivation of $P$. ostreatus in wastes of four banana tree cultivars using three combinations (pseudostem, leave and pseudostem + leave) was carried out during 49 days. The evaluation of the production was performed by means of biological efficiency (BE) (Figure 1). The substrates based on wastes of Pelipita, Thap Maeo and Caipira obtained highest BE when the pseudo-stem waste was used (45.5; 61.5 and $32.2 \%$, respectively). The substrate based on pseudo-stem + leaf showed the highest values $(44.2 \%)$ for Prata Anã. Higher results were obtained by Kurt and Buyukalaca (13) testing wastes of vine, wheat straw, rice straw and sesame straw, supplemented with wheat bran in the proportion of $2: 1$ for Pleurotus spp. cultivation and obtained values of BE of 75.5; $112.7 ; 84.6$ and $88.4 \%$, respectively. Sturion (32), using banana wastes for Pleurotus sp. cultivation, obtained values of $\mathrm{BE}$ ranging from 19.5 to $93 \%$.
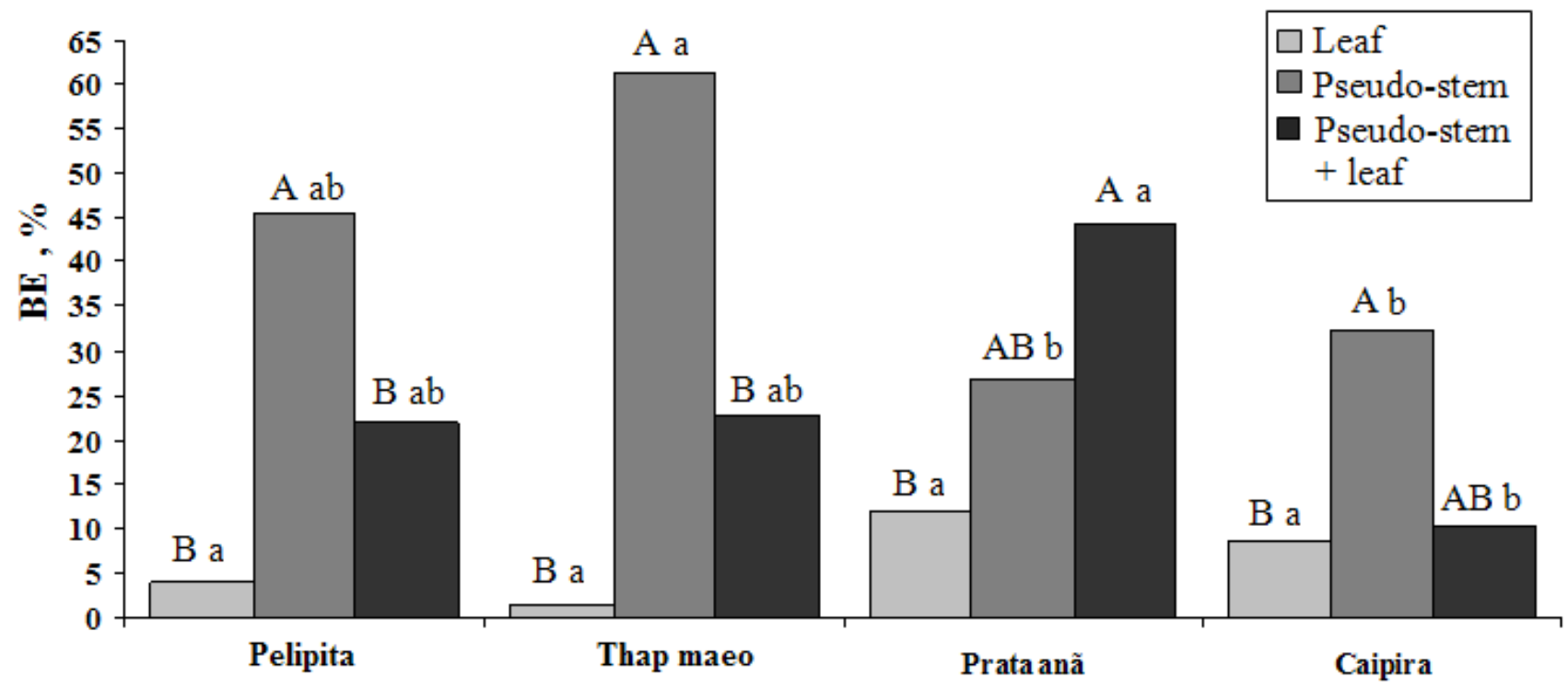

Banana cultivar

Figure 1. Biological efficiency (BE) (\%) of the 09/100 strain of Pleurotus ostreatus in different substrates based on leaf, pseudo-stem and pseudo-stem + leaf waste of four banana cultivars (Thap Maeo, Prata Anã, Caipira and Pelipita). Uppercase compare averages inside of a same banana cultivar; lowercase compare averages inside a same type of waste. Averages followed by same letter were not distinguished (Tukey, 5\%). CV $(\%)=54.62$ (average of six repetitions).

By analyzing each waste separately, it was observed that substrates based on leaves did not present significant differences among the banana cultivars (Figure 1). The highest biological efficiency was observed for Thap Maeo (61,5\%), using pseudo-stem waste. Finally, in the combination of pseudo-stem + leaf waste, the best result was obtained for the Prata Anã cultivar (44.2\%). These results confirm the influence of the banana tree cultivar in biological efficiency. Marino et al. (15) tested coconut shell sawdust supplemented with wheat and rice bran in different rates for oyster cultivation, obtaining results of $\mathrm{BE}(\%)$ among 0 to $7.5 \%$, similar to the treatments based on leaf of Thap Maeo and Pelipita, wich were 1.5 and $3.9 \%$ respectively.

Wang et al. (33), growing oyster, utilized grains from the beer process, suplemented with corn bran, wheat, rice and okara (waste from the process of soy milk); they verified 
production results similar to the present experiment, with values ranging from 2.3 to $12.3 \%$. Rany et al. (21) obtained lower results than the treatment with highest BE (pseudo-stem of Thap Maeo $-61.5 \%$ ) when growing $P$. ostreatus in banana stem, obtaining biological efficiency of 33\%. Similar values were obtained by Obodai et al. (19), who used banana leaves supplemented with rice bran as substrate for oyster mushroom cultivation, obtaining productivity of $37.15 \%$.

Belewu and Belewu (3), growing Volvariela volvacea utilizing banana waste without supplementation, obtained values of $\mathrm{BE}$ of $15.21 \%$. Still, satisfactory results were obtained by Sturion (32) using substrates based on banana leaves straw reaching 93\% of productivity, similar result obtained by Sales-Campos et al. (28), who cultivated oyster mushroom using timber and agroindustrial wastes (sugar cane and pupunha stem choped), obtaining BE ranging from $64.6 \%$ to $125.6 \%$.

In the treatments based on Pelipita pseudostem and pseudostem + Prata anã leave, biological efficiency values similar to the ones obtained in the present experiment (47.7 and
$44.2 \%$, respectively) (Figure 1) were observed by Ragunathan et al. (20) by using wheat straw and crushed sugar cane in the cultivation of $P$. sajor caju, whose EB values were 36.78 and $34.29 \%$, respectively.

Kalmis et al. (12), using residual water from olive oil processing in several concentrations as supplement for $P$. cornucopiae and P. sajor-caju with wheat straw, obtained BE of $37.7 \%$ and $65.9 \%$, respectively. Gregori et al. (11), using a mixture of wheat straw $(20 \%)$ with grains $(10 \%)$ from beer processing for $P$. ostreatus cultivation, obtained BE of $51 \%$, similar to the results obtained for the substrate utilizing Thap Maeo pseudo-stem (61.5\%) (Figure 1).

Many factors may influence the production, such as $\mathrm{C} / \mathrm{N}$ ratio and substrates composition (18). A previous analysis of the raw materials is important in order to identify their viability for cultivation (34). The results of the $\mathrm{C} / \mathrm{N}$ ratio analysis showed that concentrations ranged from 20 to 43/1 (Table 2). For oyster mushroom cultivation, the initial $\mathrm{C} / \mathrm{N}$ ratio ranges from 80 to $100 / 1$ when carried out under natural conditions. $\mathrm{C} / \mathrm{N}$ ratios required are narrower in the axenic cultivation (9).

Table 2. Centesimal composition, $\mathrm{pH}$ and $\mathrm{C} / \mathrm{N}$ ratio of the initial substrates (raw materials with supplementation of $20 \%$ of wheat bran).

\begin{tabular}{ccccc}
\hline Treatments & C (\%) & N (\%) & C:N & pH \\
\hline Pseudo-stem - Thap Maeo & 47.8 & 1.1 & $41: 1$ & 6.5 \\
Leaf - Thap Maeo & 47.8 & 2.1 & $23: 1$ & 6.6 \\
Pseudo-stem + leaf - Thap Maeo & 46.5 & 1.5 & $30: 1$ & 6.5 \\
Pseudo-stem - Prata Anã & 45.9 & 1.1 & $40: 1$ & 6.9 \\
Leaf - Prata Anã & 44.4 & 2.1 & $21: 1$ & 7.1 \\
Pseudo-stem + leaf - Prata Anã & 45.3 & 1.7 & $27: 1$ & 7.1 \\
Pseudo-stem - Pelipita & 45.0 & 1.1 & $40: 1$ & 6.7 \\
Leaf - Pelipita & 45.3 & 2.2 & $20: 1$ & 7.0 \\
Pseudo-stem + leaf - Pelipita & 44.7 & 1.4 & $33: 1$ & 6.8 \\
Pseudo-stem - Caipira & 47.2 & 1.1 & $43: 1$ & 6.0 \\
Leaf - Caipira & 45.3 & 2.2 & $21: 1$ & 6.8 \\
Pseudo-stem + leaf - Caipira & 36.5 & 1.7 & $27: 1$ & 6.4 \\
\hline
\end{tabular}

Substrates based on leaves usually obtained the minor averages of biological efficiency (Thap Maeo - 1.5\%, Pelipita 4\%, Caipira $8.5 \%$ and Prata Anã - 12\%) and analyses performed in the initial substrate showed that those substrates present higher concentration of nitrogen and narrower $\mathrm{C} / \mathrm{N}$ ratio (20 to 23/1). Therefore, it is suggested that high 
concentrations of nitrogen might affect the development of the fungus because, according to Donini et al. (8), a substrate with a high content of nitrogen might not favor the lignin degradation by the fungus, thus retarding or inhibiting the mycelial growth.

Rossi et al. (23), testing different supplementations in the micelial development of $L$. edodes, observed a minor mycelial growth speed in media with high content of rice bran. Similar results were reached by Moda et al. (16) growing $P$. sajor-caju in substrate based on crushed sugar cane using corn bran as supplement, who obtained lower BE (15.66\%), in comparison with control substrate without supplementation (26.63\%).

In general, the highest organic matter loss (OML) was obtained in the substrates based on pseudo-stem + leaf (Prata Anã - 78.6\%; Thap Maeo - 67.6\%; Pelipita - 64.8\%; Caipira $60.6 \%$ ) (Figure 2).

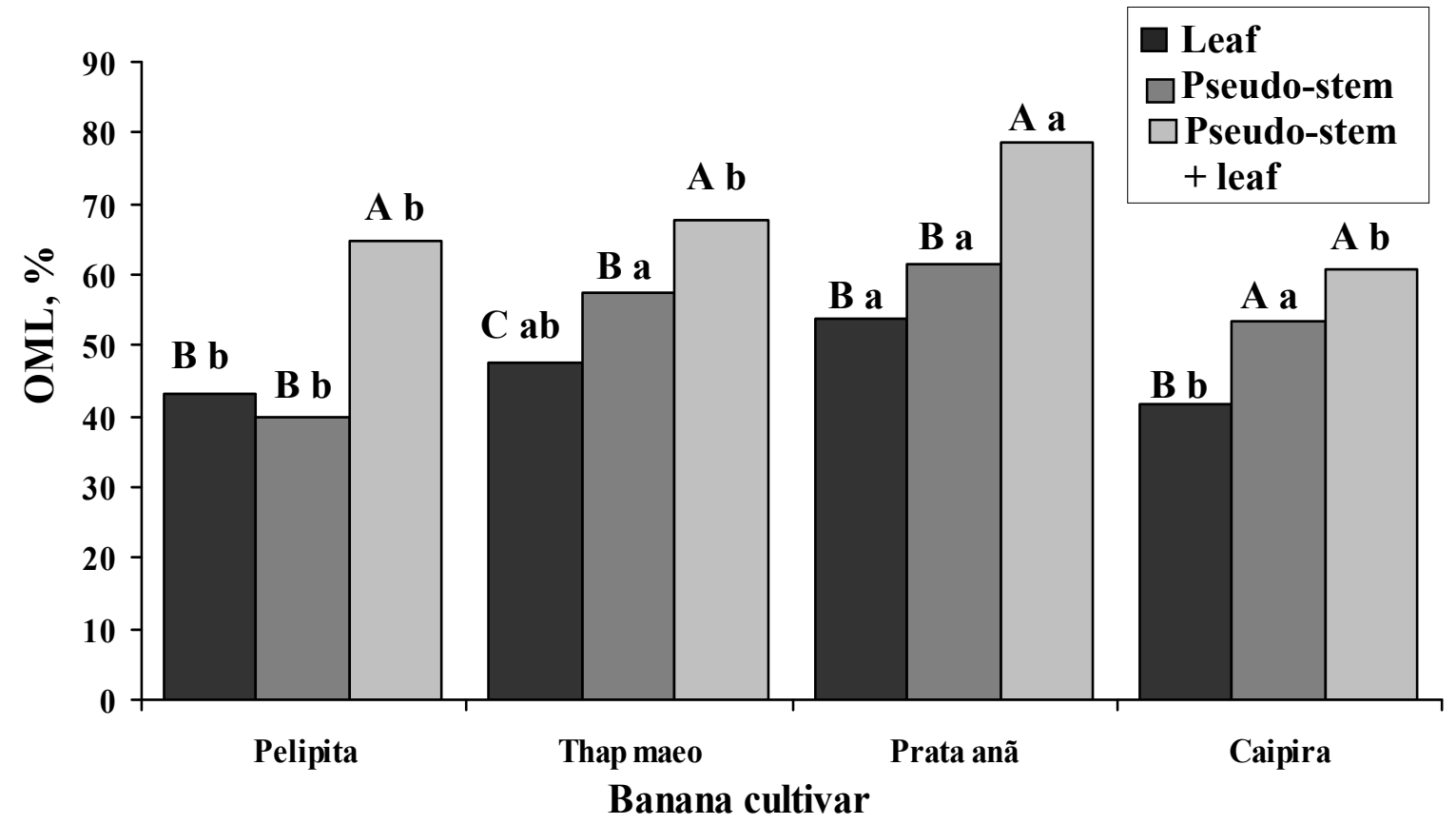

Figure 2. Organic matter loss (OML) (\%) of the substrates based on wastes (leaf, pseudo-stem and pseudo-stem + leaf) of four banana cultivars (Thap Maeo, Prata Anã, Caipira and Pelipita) by growing 09/100 strain of Pleurotus ostreatus. Uppercase compares averages inside of a same banana cultivar; lowercase compares averages inside a same type of waste. Averages followed by a same letter were not distinguished (Tukey, 5\%). CV (\%) $=5.79$ (average of six repetitions).

By analyzing the results among the wastes, the highest OML was observed in the Prata Anã cultivar (53.6\%) in substrates based on leaf. For the pseudo-stem waste, the highest values of OML were obtained for Prata Anã, Thap Maeo and Caipira cultivars, with averages of $61.5 ; 57.3$ and $53.4 \%$, respectively. Finally, in substrates based on pseudostem + leaf waste, the highest OML was obtained for Prata Anã $(78.6 \%)$.
According to Zadrazil (34), a high OML rate is not always correlated with an increased biological efficiency because OML occurs due to $\mathrm{CO}_{2}$ and $\mathrm{H}_{2} \mathrm{O}$ losses during the metabolism of microorganisms and not only from the removal of materials from basidiomata construction. By comparing organic matter loss (\%) (Figure 2) with biological efficiency (Figure 1), we observed that most treatments did not show relation between both parameters, i. e., the substrates with less OML 
provided the highest $\mathrm{BE}$. Similar results of $\mathrm{BE}$ that ranged from 59.91 to 71.83 were obtained by Sales-Campos et al. (28). The authors report that OML (\%) was not related to $\mathrm{BE}$ because the substrates that present highest productivity were not the ones presenting highest OML. Lower OML (38.7\%) was obtained by Ruegger et al. (25) cultivating Oudemansiella canarii in composts based on crushed sugar cane. In that situation, the highest OML was related to BE. Thus, OML cannot be an indicative parameter of productivity because there was no consonance between OML and BE values observed in this experiment and in literature.

\section{CONCLUSION}

1. All the banana cultivars tested were favorable for $P$. ostreatus cultivation.

2. The substrate based on banana pseudo-stem is the most recommended for oyster mushroom cultivation.

3. The highest organic matter loss occurred in the substrates based on pseudo-stem + leaf of banana tree waste.

4. The use of banana tree wastes for the cultivation of $P$. ostreatus shows itself as a promising raw material due to its great local availability and low or no cost. Besides, it helps in the reduction of its disposal in the environment and the consequent impacts.

\section{ACKNOWLEDGEMENTS}

To the Coordination of Improvement of Personal of Superior Level, for offering the Master scholarship to the first author.

\section{REFERENCES}

1. Abreu, L.D.; Marino, R.H.; Mesquita, J.B; Ribeiro, G.T. (2007). Degradação da madeira de Eucalyptus sp. por basidiomicetos de podridão branca. Arq. Inst. Biol. 74 (4), 321-328.
2. Alves, E.J.; Oliveira, M.A. (1999). Práticas culturais. In: Alves, E.J. A cultura da banana: Aspectos técnicos, socioeconômicos e agroindustriais. Brasília: Embrapa-SPI. p. 335-351.

3. Belewu, M.A.; Belewu, K.Y. (2004). Cultivation of mushroom (Volvariella volvaceae) on banana leaves. Afr. J. Biotechnol. 4 (12), 1401-1403.

4. Bonatti, M.; Furlan, S. Karnopp, P.; Soares, H.M. (2004). Evaluation of Pleurotus ostreatus and Pleurotus sajor-caju nutritional characteristics when cultivated in different lignocellulosic wastes. Food Chem. 88 (3), $425-428$.

5. Carvalho, C.S.M.; Sales-Campos, C.; Andrade, M.C.N. (2010). Mushrooms of the Pleurotus genus: a review of cultivation techniques. Interc. 35 (3), 177-182.

6. Chertman, M. (2007). Secagem de papel produzido através de pseudocaule de bananeira. São Paulo, Brasil, 107. (M.Sc. Dissertation. Escola Politécnica. USP).

7. Coelho, R.R.; Mata, M.E.C.; Braga, M.E.D. (2001). Alterações dos componentes nutricionais do pseudocaule da bananeira quando processado visando sua transformação em palmito Rev. Bras. Prod. Agroind. 3 (1), 21-30.

8. Donini, L.P.; Bernardi, E.; Minotto, E.; Do Nascimento, J.S. (2005). Desenvolvimento in vitro de Pleurotus spp. sob a influência de diferentes substratos e dextrose. Arq. Inst. Biol. 72 (3), 331-338.

9. Eira, A.F.; Minhoni, M.TA. (1997). Manual do cultivo do "Hiratake” $e$ "Shimeji” (Pleurotus spp.). Fundação de Estudos e Pesquisas Agrícolas e Florestais, Botucatu, SP.

10. FAOSTAT. Food and Agriculture Organization of the United Nations. Agricultural Production - Crops Primary. 2008. Disponível em $<$ http://faostat.fao.org/site/567/DesktopDefault.aspx?PageID=567\#ancor >. Acesso em: 10 jan. 2010.

11. Gregori, A.; Svagelj, M.; Pahor, B.; Berovic, M.; Pohleven, M. The use of spent brewery grains for Pleurotus ostreatus cultivation and enzyme production. New Biotechnol. 25 (2/3), 157-161.

12. Kalmis, E.; Azbar, N., Yildiz, H.; Kalyoncu, F. (2008). Feasibility of using olive mill effluent (OME) as a wetting agent during the cultivation of oyster mushroom, Pleurotus ostreatus, on wheat straw. Bioresource Technol. 99 (1), 164-169.

13. Kurt, S.; Buyukalaca, S. (2010). Yield performances and changes in enzyme activities of Pleurotus spp. (P. ostreatus and P. sajor-caju) cultivated on different agricultural wastes. Bioresource Technol. 101 (9), 3164-3169.

14. LANARV. Laboratório de Referência Vegetal. Análise de fertilizantes e inoculantes: métodos oficiais. Brasília: Secretaria Nacional de Defesa Agropecuária, 1988. 104 p.

15. Marino, R.H.; Abreu, L.D.; Mesquita, J.B.; Ribeiro, G.T. (2008). Crescimento e cultivo de diferentes isolados de Pleurotus ostreatus 
(Jacq.: fr.) Kummer em serragem da casca de coco. Arq. Inst. Biol. 75 (1), 29-36.

16. Moda. E.M.; Horii. J.; Spoto, M.H.F. (2005). Edible Mushroom Pleurotus sajor-caju production on washed and supplemented sugarcane bagasse. Sci. Agr. 62 (2), 127-132.

17. Motato, R.; Mejía, I.A.; León, A. (2006). Evaluación de los residuos agroindustriales de plátano (Musa paradisíaca) y aserrín de abarco (Cariniana piriformes) como sustratos para el cultivo del hongo Pleurotus djamor. Vitae. 13 (1), 24-29.

18. Nair, N.G. (1982). Substrates for Mushroom Production. In: Chang, S.T.; Quimio, T.H. (eds). Tropical mushrooms: Biological nature and cultivation methods. The Chinese University Press, Hong Kong, p. 4758.

19. Obodai, M.; Cleland-okine, J.; Vowotor, K.A. (2003). Comparative study of the growth and yield of Pleurotus ostreatus on different lignocellulosic by-products. J. Ind. Microbiol. Biot. 30 (3), 146-149.

20. Ragunathan, R.; Gurusamy, R.; Palaniswamy, M.; Swaminathan, K. (1996). Cultivation of Pleurotus spp. on various agro-residues. Food Chem. 33 (1), 139-144.

21. Rani, P.; Kalyani, N.; Prathiba, K. (2008). Evaluation of Lignocellulosic Wastes for Production of Edible Mushrooms. Appl. Biochem. Biotech. 151 (1), 151-159.

22. Reddy, G.V.; Ravindra Babu, P.; Komaraiah, P.; Roy, K.R.R.M.; Kothari, I.L. (2003). Utilization of banana waste for the production of lignolytic and cellulRolytic enzymes by solid substrate fermentation using two Pleurotus species (P. ostreatus and P. sajor-caju). Process Biochem. 38 (10), 1457-1462.

23. Rossi, I.H.; Monteiro, A.C.; Machado, J.O. (2001). Desenvolvimento micelial de Lentinula edodes como efeito da profundidade e suplementação do substrato. Pesq. Agropec. Bras. 36 (6), 887-891.

24. Royse, D.J. (2003). Cultivation of oyster mushroom. College of Agricultural Sciences/The Pennsylvania State University Park University: Agricultural Research and Cooperative Extension. Disponível em < http://pubs.cas.psu.edu/FreePubs/pdfs/UL207.pdf>.
Acesso em: 15 ago. 2011.

25. Ruegger, M.J.S.; Tornisielo, S.M.T.; Bononi, V.L.R.; Capelari, M. (2001). Cultivation of the edible mushroom Oudemansiella canarii (Jungh.) höhn. in lignocellulosic substrates. Braz. J. Microbiol. 32 (3), 211-214.

26. Sales-Campos, C.; Andrade, M.C.N. (2011). Aproveitamento de resíduos madeireiros para o cultivo do cogumelo comestível Lentinus strigosus de ocorrência na Amazônia. Acta Amaz. 41(1), 1-8.

27. Sales-Campos, C. (2008). Aproveitamento de resíduos madeireiros e da agroindústria regional para o cultivo de fungos comestiveis de ocorrência na região amazônica. 2008. 197p. (PhD Thesis, Universidade Federal do Amazonas. UFAM).

28. Sales-Campos, C.; Minhoni, M.T.A.; Andrade, M.C.N. (2010). Produtividade de Pleurotus ostreatus em resíduos da Amazônia. Interc. 35 (10), 198-201.

29. Santos, V.M.C.S.; Cassou, R.; Gern, R.M.M.; Mendonça, M.M.; Furlan, S.A. (2000). Estudo da fração de inóculo e da suplementação de palha de bananeira para a produção de Pleurotus sajor-caju. Rev. Saúde e Amb. 1 (1), 64-67.

30. Siqueira, F.G; Martos, E.T; Silva, R; Dias, E.S. (2011). Cultivation of Pleurotus sajor-caju on banana stalk and Bahia grass based substrates. Horticultura Brasileira 29: 199-204.

31. Soffner, M.L.A.P. (2006). Produção de polpa celulósica a partir de engaço de bananeira. 56p. (M.Sc. Dissertation. Escola Superior de Agricultura. USP).

32. Sturion, G.L. (1994). Utilização da folha da bananeira como substrato para o cultivo cogumelo (Pleurotus spp.). 147p. (M.Sc. Dissertation. Escola Superior de Agricultura. USP).

33. Wang, D.; Sakoda, A. Suzuki, M. (2001). Biological efficiency and nutritional value of Pleurotus ostreatus cultivated on spent beer grain. Biores. Technol. 78 (3), 293-333.

34. Zadrazil, F. (1978) Cultivation of Pleurotus. In: Ghang S.T and Hayes, W.A (Eds.) The Biology and Cultivation of Edible Mushrooms. Academic Press. Nova Yorque, EEUU. pp. 521-557. 